\title{
Carbon monoxide contributes to the regulation of vascular tonus in renal resistance arteries in spontaneously hypertensive rats
}

\section{Karbon monoksit, spontan hipertansif sıçanların renal direnç arterlerinde vasküler tonusun duizenlenmesine katkıda bulunur}

\section{Günnur KOÇER ${ }^{1}$, Seher NASIRCILAR², Filiz BASRALI ${ }^{3}$, Oktay KURU ${ }^{4}$, Ümit Kemal ŞENTÜRK ${ }^{3}$}

\section{ABSTRACT}

Objective: Carbon monoxide (CO), an end product of heme oxygenase $(\mathrm{HO})$ involved in the regulation of vascular tone, may show a compensatory effect in the course of hypertension. This study aimed to assess the effects of the $\mathrm{HO} / \mathrm{CO}$ system on the vascular tone of renal resistance arteries in spontaneously hypertensive rats (SHRs).

Methods: The contribution of endogenous $\mathrm{CO}$ to vascular tone in renal resistance arteries was evaluated by the phenylephrine (Phe) contraction response with or without an $\mathrm{HO}$ inhibitor. The effect of the exogenous CO relaxation response was assessed by a CO releasing molecule (CORM). The mechanism of the $\mathrm{CO}$ relaxation effect was evaluated by a guanylate cyclase inhibitor, ODQ, or a potassium channel blocker, TEA. HO-1 and HO-2 enzyme protein expressions in renal resistance arteries were determined by Western blot analysis.

Results: Phe-induced constriction responses were higher in renal resistance arteries of SHRs compared to control animals. The extent of the same type of constriction was even higher in the SHR group after inhibition of $\mathrm{CO}$ production. Relaxation responses to a CO donor, CORM, were greater in the SHR group versus the control group. TEA, but not ODQ, suppressed CORM

\section{ÖZET}

Amaç: Vasküler tonusun düzenlenmesinde yer alan karbon monoksit (CO), hipertansiyon gelișimi sırasında kompansatuar etki gösterebilir. Bu çalıșma, spontan hipertansif sıçanlarda (SHR) HO / CO sisteminin renal direnç arterlerinin vasküler tonusu üzerine etkilerini değerlendirmeyi amaçlamıștır.

Yöntem: Renal direnç arterlerinde endojen CO'nun vasküler tonusa katkısı, bir HO inhibitörü varlığında ve yokluğunda fenilefrin (Phe) kontraksiyon yanitı ile test edildi. Ekzojen CO gevșeme yanıtı da CO donörü (Carbon monoxide-releasing molecule (CORM)) kullanılarak değerlendirildi. CO gevșeme yanıtının mekanizması, guanilat siklaz inhibitörü (ODQ) veya potasyum kanal blokörü TEA ile değerlendirildi. Renal direnç arterlerindeki $\mathrm{HO}-1$ ve $\mathrm{HO}-2$ protein ekspresyonları Western blot analizi ile saptandı.

Bulgular: SHR'lerde kontrol grubuna kıyasla Phe'ye verilen kasılma yanıtı anlamı olarak yüksekti $(p<0,05)$. HO inhibisyonu ile CO üretimi engellendiğinde SHR'de kasılma yanıtı daha da arttı $(p<0,05)$. SHR sıçanlarda CORM'a verilen gevșeme yanıtları da daha yüksekti $(p<0,05)$. Her iki grupta da CORM yanıtlarını ODQ baskılamazken TEA anlamlı

${ }^{1}$ Near East University, Department of Physiology, Nicosia, TRNC

${ }^{2}$ Alanya Alaaddin Keykubat University, Department of Physiotherapy and Rehabilitation, Antalya, Turkey

${ }^{3}$ Akdeniz University, Department of Physiology, Antalya, Turkey

${ }^{4}$ Muğla Sıtkı Koçman University, Department of Physiotherapy and Rehabilitation, Muğla, Turkey

Illetişim / Corresponding Author : Günnur KOÇER

Yakın Doğu Bulvarı, YDÜ Tıp Fakültesi Fizyoloji AD Kat: 2 Oda: 212, 99138 Lefkoşa - K.K.T.C.

E-posta / E-mail : gunnurkocer@neu.edu.tr

Geliş Tarihi/Received : 20.03.2020 Kabul Tarihi / Accepted : 16.07.2020

DOI ID : 10.5505/TurkHijyen.2020.76736

Koçer G, Nasırcılar S, Basralı F, Kuru O, Şentürk ÜK. Carbon monoxide contributes to the regulation of vascular tonus in renal resistance arteries in spontaneously hypertensive rats. Turk Hij Den Biyol Derg, 2020; 77(4): 421-430 
responses in both groups. HO-2 protein expression patterns were not different between the groups, while HO-1 expression was remarkably higher in SHRs when compared to that in control rats.

Conclusion: Consequently, our results revealed a CO-based compensatory effect in SHRs by the induction of $\mathrm{CO}$ production and an increase in its bioavailability.

Key Words: CO, HO-1, SHR, renal resistance artery olarak baskıladı $(\mathrm{p}<0,01)$. HO-2 protein ekspresyonu açısından gruplar arasında farklı olmamakla birlikte HO-1 ekspresyonu SHR'lerde kontrol grubuna göre önemli ölçüde daha yüksekti.

Sonuç: Sonuç olarak verilerimiz, SHR'lerin böbrek direnç arterlerinde karbon monoksidin kompansatuar etkisi olduğunu ortaya koymaktadır.

Anahtar Kelimeler: CO, HO-1, SHR, renal direnç arteri

\section{INTRODUCTION}

Carbon monoxide (CO) is one of the recently accentuated relaxing mediators contributing to vascular tone. $\mathrm{CO}$ is endogenously produced by the heme oxygenase $(\mathrm{HO})$ enzyme via degradation of heme substances and acts as an important regulator of vascular tone and blood pressure (1, $2)$. Its vasodilator effect and consequent decrease in peripheral vascular resistance is based on the interaction with soluble guanylate-cyclase (sGC) or with the calcium-activated potassium channels located in vascular smooth muscle cells (2-4). CO and nitric oxide (NO) have similar physiological implications, and there is cross-talk between the two, which affects the production and function of each other (5). Deterioration of NO metabolism and function is a well-known process in the development of spontaneously hypertensive rats (SHRs). Accordingly, the expressions of $\mathrm{HO}-1$ and $\mathrm{HO}-2$ enzymes, which are endogenous sources of $\mathrm{CO}$ production, are upregulated during the course of hypertension to compensate for NO deficiency (5). Despite similar biological effects, $\mathrm{CO}$ and NO cannot replace each other. In some instances, their functions may be different; in others, their functions may be synergistic or antagonistic (6). Low CO concentrations induce
NO release by eNOS activation, while high levels of CO reduce eNOS enzyme activity (7). The effects of the $\mathrm{HO} / \mathrm{CO}$ system on renal vascular tone are well described. HO-1 and HO-2 expressions are present in both vascular and tubular structures of the kidney (8). CO acts as a vasodilator in the renal circulation regardless of being endogenous or exogenous $(3,4$, 8,9 ), and in vivo studies have demonstrated that the inhibition of $\mathrm{HO}$ enzymes reduces renal blood flow and depresses renal function (8, 10-12).

$\mathrm{CO}$, produced during the development of hypertension, has protective effects on the kidney. For instance, besides its blood pressure-lowering effects by the stimulation of the HO-1 enzyme, shown in the one kidney - one clip $(1 \mathrm{~K} 1 \mathrm{C})$ renovascular hypertension model (13), and the angiotensin II (Ang II) salt-sensitive hypertension model stimulating renal damage (14), CO can also reduce renal damage. However, alterations in the $\mathrm{HO} / \mathrm{CO}$ system in SHR kidneys are still unknown.

The kidney has important implications in blood pressure regulation, and renal damage by hypertension is common (15-17). Functional impairment of the renal vascular bed is an early sign of renal damage in both SHRs and other experimental 
hypertension models. Renal vascular damage is first seen in the juxtamedullar cortex $(18,19)$, followed by an elevation in systemic blood pressure (20).

Hypertension leads to vascular damage of resistance vessels in the periphery, but renal vasculature is affected as well (20). There are no data elucidating the process, possible alterations in $\mathrm{CO}$ production, and $\mathrm{CO}$ bioavailability in renal resistance arteries of SHRs. It is speculated that CO acts as a backup for the NO molecule, and thus, the changes in the $\mathrm{HO} / \mathrm{CO}$ system in resistance vessels of SHRs are worth investigating. Our present study aims to investigate if $\mathrm{CO}$ affects renal resistance arteries of SHR functionally, and if so, to evaluate the possible mechanisms involved in the process.

\section{MATERIAL and METHOD}

\section{Animals}

Animals in the hypertensive group were 1215 week-old SHRs, while Wistar Kyoto rats (WKY) represented the age-matched normotensive group (Harlan Laboratories, Israel). The rats were housed on a $12: 12 \mathrm{~h}$ light-dark cycle at $23 \pm 2{ }^{\circ} \mathrm{C}$ with free access to standard rat chow and drinking water. All animal handling and experimental procedures were approved by the Animal Care and Usage Committee of Akdeniz University.

Systolic blood pressure measurements were performed using a noninvasive tail-cuff method. Blood pressure data were obtained with a MAYBPHR 9610-PC unit and an MP 150 data-acquisition system (BIOPAC Systems; Santa Barbara, CA, USA) as measurements were completed immediately before euthanizing the animals.

\section{Preparation of vessels}

The animals were euthanized under pentobarbital anesthesia by withdrawing the blood from the abdominal aorta. Whole kidney samples were immediately removed and then transferred to a dissecting dish containing a cooled Krebs solution (110
$\mathrm{mM} \mathrm{NaCl}, 5 \mathrm{mM} \mathrm{KCl}, 24 \mathrm{mM} \mathrm{NaHCO3,} 1 \mathrm{mM} \mathrm{KH2PO4,}$ $1 \mathrm{mM}$ MgSO4, $2.5 \mathrm{mM} \mathrm{CaCl}$, $10 \mathrm{mM}$ glucose, and 0.02 $\mathrm{mM}$ EDTA). Resistance arteries of renal tissues (the second-order; 2A branches of the renal artery; 200$220 \mu \mathrm{m}$ in diameter) were carefully isolated and then dissected into 2-mm-long pieces under a dissection microscope. Vessel segments were then mounted onto a wire myograph chamber (EMKA Technologies, Paris, France), and their basal wall tensions were calculated using computer software (Normalize v1.0, EMKA Technologies, Paris, France). All vessel samples were rested for an hour at $37{ }^{\circ} \mathrm{C}$ and maintained at the determined baseline tension.

\section{Protocols}

The equilibration period was followed by a preconditioning and vitalization process by adding $20 \mathrm{mM} \mathrm{KCl}$ and $10^{-7} \mathrm{M}$ phenylephrine (Phe, Sigma, St. Louis, USA)]. All vessel rings were then precontracted by a submaximal dose of Phe $\left(10^{-6} \mathrm{M}\right)$ and relaxation responses to $10^{-6} \mathrm{M}$ acetylcholine (Sigma, St. Louis, USA) were evaluated to examine the presence of endothelium; > 70\% relaxation represented acceptable level. NO production was typically inhibited in $\mathrm{CO}$ studies to observe the true CO-based effects by the addition of a nonspecific NOS inhibitor L-NAME (1 mM, Sigma, St. Louis, USA) to the bath solution during each of the following steps in our experimental protocols. The chambers were left for 30 min resting intervals prior to the next protocol application, explained below.

\section{Endogenous $\mathrm{CO}$ responses}

Cumulative contraction responses to Phe $\left(10^{-9}\right.$ to $3 \times 10^{-5} \mathrm{M}$ ) were recorded, and the vessels were then incubated with the $\mathrm{HO}$ inhibitor, chromium mesoporphyrin (CrMP; $30 \mu \mathrm{M}$, Frontier, Utah, USA) for $30 \mathrm{~min}$ to repeat the recording of Phe dose-response curves. The expected increase in the Phe-induced contraction response was used to demonstrate the contribution of endogenous $\mathrm{CO}$ to vascular tone after the suppression of CO production by CrMP treatment. 


\section{Exogenous $\mathrm{CO}$ responses}

Cumulative doses $\left(10^{-9}\right.$ to $\left.3 \times 10^{-4} \mathrm{M}\right)$ of tricarbonyldichlororuthenium (II) dimer (CORM, carbon monoxide-releasing molecule, Sigma-Aldrich, St. Louis, USA) were used to monitor vasodilation responses in vessel rings pretreated with $3 \times 10^{-6} \mathrm{M}$ Phe.

\section{Determination of $\mathrm{HO}-1$ and 2 expressions}

The collected arterial tissue samples were stored at $-80{ }^{\circ} \mathrm{C}$ before assessing the expression levels of $\mathrm{HO}$ isoforms. Then, $100 \mu \mathrm{g}$ of tissue protein lysates were applied per lane for SDS-PAGE (in $12.5 \%$ gel) separation, followed by electroblotting to transfer the samples onto PVDF membranes. A 5\% non-fat dry milk medium was used for the blocking process before the membranes were incubated overnight at $4{ }^{\circ} \mathrm{C}$ room temperature with primary antibodies: $\mathrm{B}$-actin (1:500; Abcam, Cambridge, UK), HO-1 (1:1000; StressGen, Victoria, BC, Canada), and HO-2 (1:1000; StressGen, Victoria, BC, Canada). All membranes were then treated for $1 \mathrm{~h}$ with appropriate HRP- conjugated secondary antibodies (1:80.000; Sigma, St. Louis, USA). The Image-J program was used for densitometric analysis and quantification of relative changes in protein expression.

\section{Statistical analysis}

The results are presented as mean $\pm \mathrm{SE}$. Nonrepeated measurements (blood pressure, HO expression, and the maximum contraction/dilation responses-Emax) were evaluated by $\mathrm{t}$-test (between groups) and paired t-test (within groups). Differences between the dose-response curves were tested for significance using two-way ANOVA for repeated measurements, followed by the Newman-Keuls post hoc test. A value of $p<0.05$ was considered statistically significant.

\section{RESULTS}

Mean arterial blood pressure levels were significantly higher in SHRs compared to the WKY control group $(p<0.001$, Fig. 1$)$.

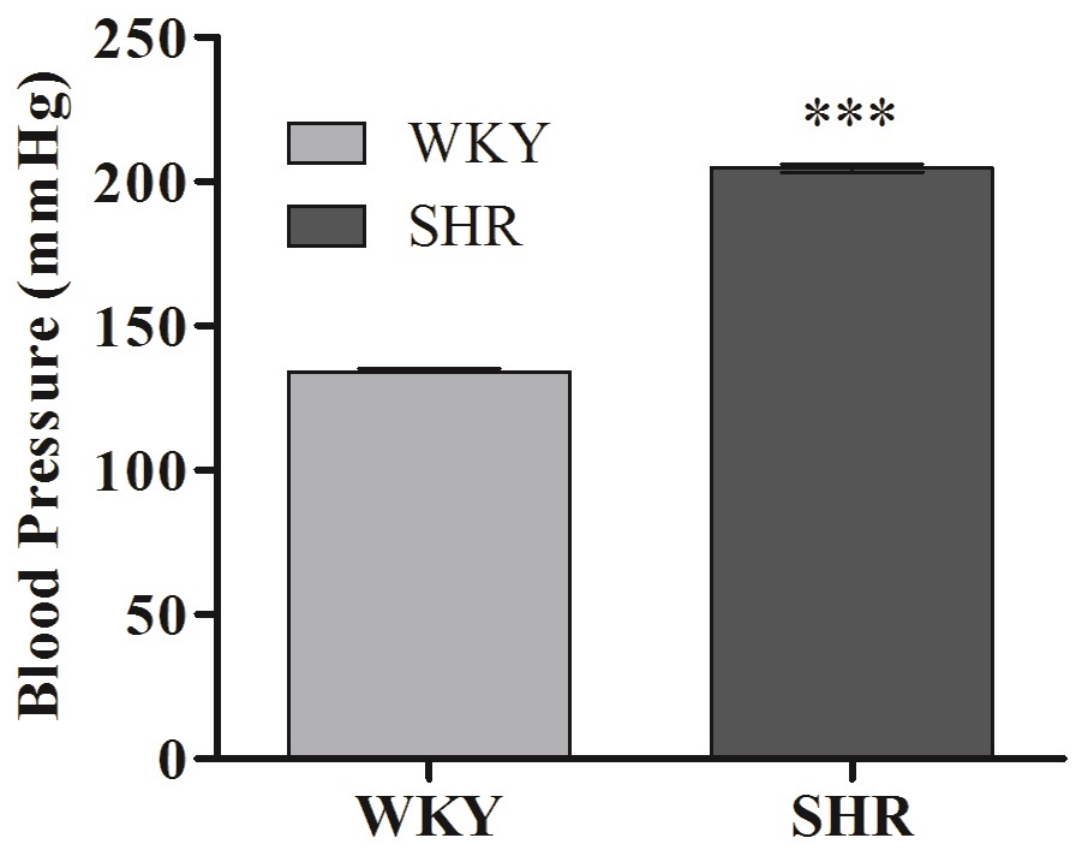

Figure 1. Systolic blood pressure $(\mathrm{mmHg})$. ${ }^{* * *} p<0.001$ difference from WKY 


\section{Endogenous CO responses}

The differences between the contraction response to Phe and the endogenously produced $\mathrm{CO}$ response after pre-incubation with CrMP and exposure to Phe are shown in Fig. 2. Contraction dose-response curves to Phe were significantly higher in the SHR group compared to normotensive animals $(p<0.05$, Fig. 2A). When the HO inhibitor CrMP was used for pre-incubation prior to Phe application, no statistical change in contraction responses was seen in the WKY group, while a significant increase was observed in the SHR group $(p<0.05$, Fig. $2 B)$. Comparison of Emax values of Phe constriction between the groups demonstrated significantly higher values in the SHR group than the WKY group $(p<0.05$, Fig. 2B). Comparison of Emax values of Phe contraction between samples with and without CrMP preincubation showed no difference in the normotensive group, but a statistically significant difference in the hypertensive group ( $p<0.05$, Fig. $2 B)$.
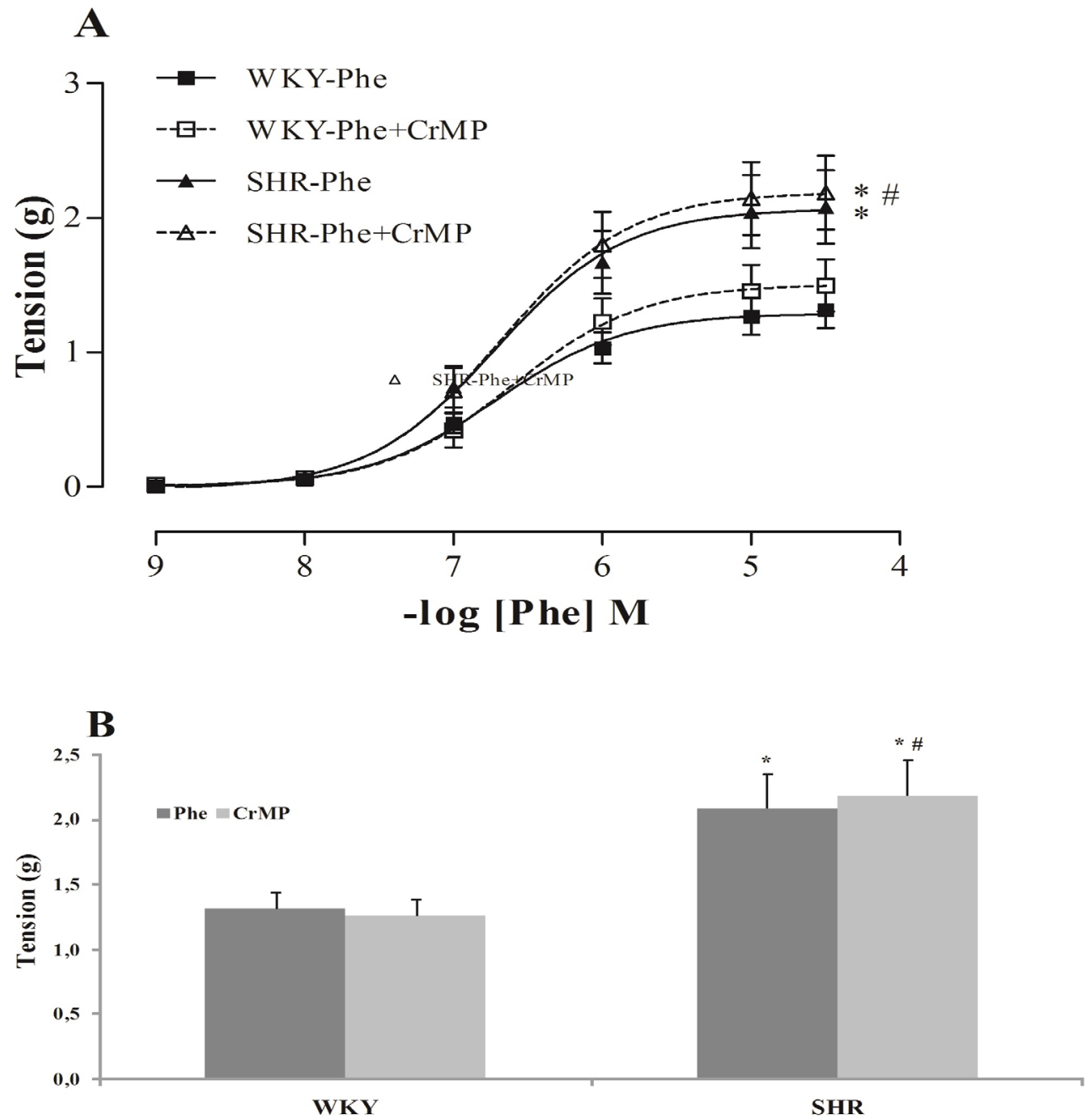

Figure 2. Constriction responses in renal resistance artery rings induced by Phe A; Dose-response curves to Phe at baseline and in the presence of $\mathrm{HO}$ inhibitor CrMP, $\mathrm{B}$; Emax values at baseline and in the presence of $\mathrm{HO}$ inhibitor CrMP.

${ }^{*} p<0.05$ difference from WKY, \# $p<0.05$ difference from basal Phe contractions for each group 


\section{Exogenous $\mathrm{CO}$ responses}

Relaxation dose-response curves to the CO donor, CORM, as well as Emax values, were statistically higher in the SHR group compared to the WKY group $(p<0.01$, Fig. $3 A$ and $D)$. However, CORM responses after pre-incubation with ODQ or TEA were similar in WKY (Fig. 3B and D) and SHR (Fig. 3C-D) groups. CORM relaxation patterns were similar in both the groups with or without ODQ pretreatment, while TEA pre-incubation resulted in suppression of the CORM- induced relaxation response and Emax values in both groups $(p<0.01)$.

\section{HO-1 and 2 expressions}

No differences in HO-2 protein expression was observed between the groups (Fig. 4B), but HO-1 expression was found to be higher in the SHR group compared to the normotensive control group $(p<0.01$, Fig. 4A).
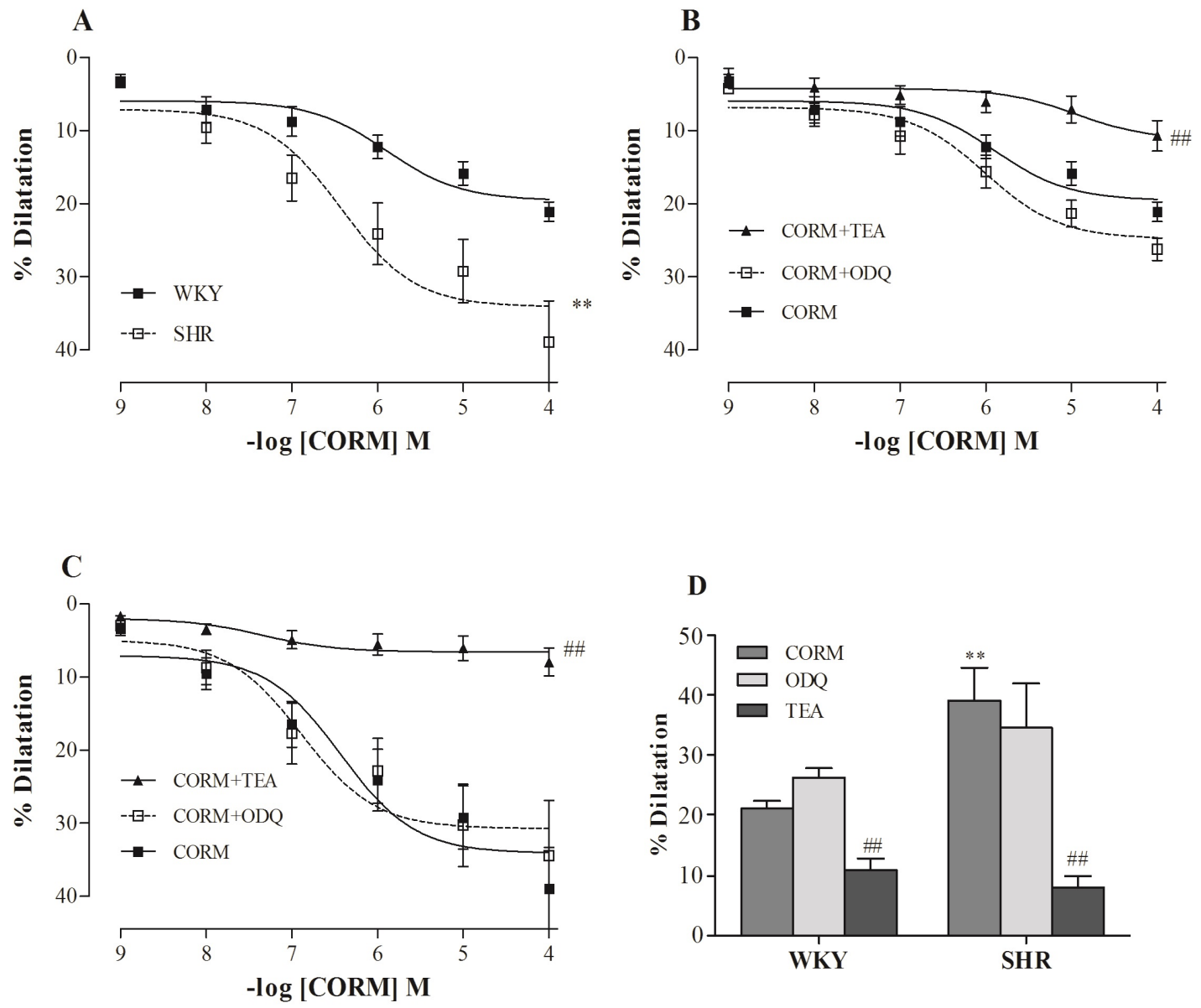

Figure 3. Dose-response curves in renal resistance artery rings for dilatation induced by CORM and maximal dilatation responses,

A; Curves representing CORM responses in both groups,

$\mathrm{B}$; CORM responses in WKY at baseline and after pre-incubation with ODQ or TEA,

C; CORM responses in SHRs at baseline and after pre-incubation with ODQ or TEA,

D; Emax values at baseline and after pre-incubation with QDQ or TEA in experimental groups.

${ }_{* *} p<0.01$ difference from WKY, \#\# $p<0.01$ difference from basal CORM within groups 

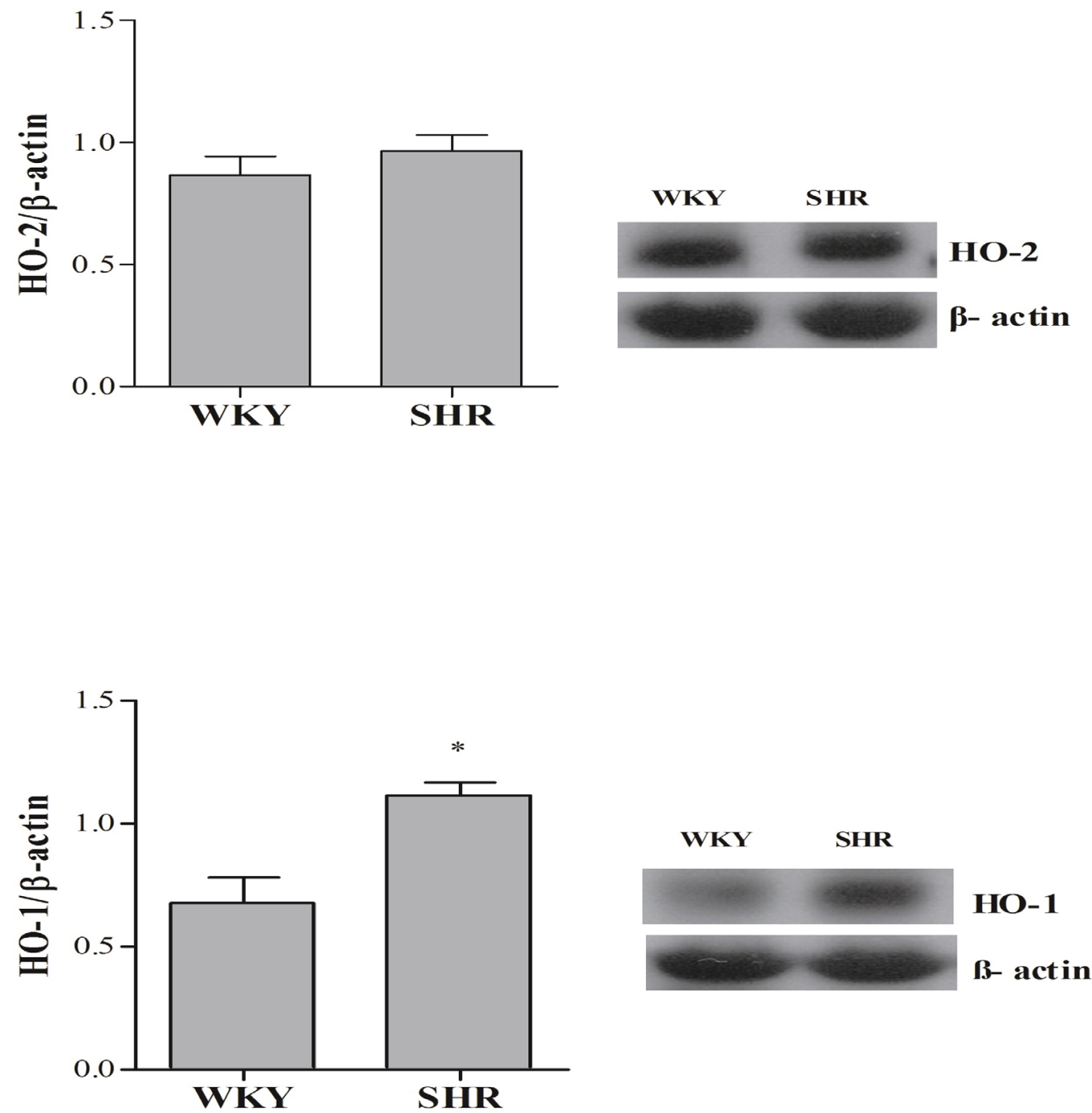

Figure 4. $\mathrm{HO}$ enzyme expression in renal resistance artery rings.

A; HO-1 expression,

B; HO-2 expression.

${ }^{*} \mathrm{p}<0.05$ difference from WKY

\section{DISCUSSION}

The kidneys are most the important organs to be affected by hypertension. This study investigated the contribution of the $\mathrm{HO} / \mathrm{CO}$ system to vascular tone in renal resistance arteries in SHRs. Important findings of our study are; 1 - The vasodilatory effect and endogenously contribution of $\mathrm{CO}$ increases because of the elevated HO-1 enzyme expression in renal resistance arteries in SHRs. 2-The vasodilatation response of $\mathrm{CO}$ primarily is induced by potassium channels in renal resistance arteries.

The contribution of $\mathrm{CO}$ to the regulation of blood pressure has been shown in various experimental hypertensive models (21). We used SHR, which is a model of essential hypertension in humans, in our study. As expected, the blood pressure values were found to be significantly higher in the SHR group 
compared to the normotensive controls. In addition, greater vasoconstrictive responses in renal resistance arteries of SHRs reflect an increase in vascular tone. The increase in vasoconstrictive responses in SHRs induced by Phe is presented in other studies as well (21-23). However, the original finding of our study is that $\mathrm{CO}$ contributes to the increased vascular responses of renal resistance arteries in SHRs. Pheinduced constrictive responses in hypertensive animals, repeated after CRMP incubation (HO enzyme inhibitor), were seen in SHRs to a greater extent than in controls. The additional increase in the already elevated vascular tone in SHRs can be explained by the lack of compensatory effect of $\mathrm{CO}$ due to $\mathrm{HO}$ inhibition. However it is well known that the role of $\mathrm{CO}$ as a vasodilator and protective agent in renal circulation $(2,12,24,25)$ under physiological and some pathophysiological conditions, its protective effects against to elevated vascular tone in SHR was shown first time in this study.

The findings of Western blotting procedure for $\mathrm{HO}$ protein expression levels in renal resistance arteries support the hypothesis that $\mathrm{CO}$ has compensatory effects against the constrictive effects of Phe. Our expression results for the HO-2 enzyme, the constitutive form of $\mathrm{HO}$, showed no differences between the groups, similar to the findings from other studies $(26,27)$. However, the expression of $\mathrm{HO}-1$, the inducible form of $\mathrm{HO}$, was significantly higher in the SHR group compared to the controls. Taken together, these results suggest that HO-1derived $\mathrm{CO}$ contributes to the alleviation of the increased vascular tone in renal vascular tissues of SHRs. After the detection of elevated endogenous CO production in hypertensive animals, we proceeded to examine possible changes in responses to $\mathrm{CO}$ by evaluating the relaxation responses to CORM, a CO donor. Renal resistance arteries in the SHR group exhibited significantly increased dilation of $39 \%$ in SHR and $21 \%$ in WKY controls after CORM incubation.

CO exerts its vasodilator effect mainly by increasing the intracellular levels of CGMP (28) or by opening calcium-activated potassium channels (BKCa) in smooth muscles (29). The effects of CO on the relaxation mechanism were investigated by the inhibition of cGMP production and by the blockage of potassium channels by ODQ and TEA, respectively. Relaxation responses were not altered in either group after incubation with ODQ, but TEA incubation suppressed CORM-induced dilation by inhibiting potassium channels; a greater decline in relaxation responses was observed in the SHR group (39\% to $7.9 \%$ ) compared to the WKY group ( $21 \%$ to $10 \%$ ). These data suggest a role of potassium channels in CO-dependent relaxation responses in renal resistance arteries of SHRs. These results are supported by previous studies, which revealed an increased conductance of potassium ions and $\mathrm{BKCa}$ density in aortas of SHRs $(30,31)$. A higher number of BKCa channels on the vascular smooth muscle surfaces may lead to improved vasodilation responses to exogenously applied CO.

The results of the present study indicate that $\mathrm{CO}$ production stimulated by an increase in $\mathrm{HO}-1$ enzyme expression contributes to the suppression of vascular tone in renal resistance arteries. Relaxation responses to exogenous $\mathrm{CO}$ in renal resistance arteries were also improved. The compensatory effect of $\mathrm{CO}$ in renal resistance arteries of hypertensive animals is an important finding for delay in impairment in renal function. 


\section{ACKNOWLEDGEMENT}

This study was supported by Akdeniz University Research Projects Unit (Project number 04.01.0200.004).

\section{REFERENCES}

1. Chan EC, Dusting GJ, Liu GS, Jiang F. Redox mechanisms of the beneficial effects of heme oxygenase in hypertension. J Hypertens. 2014;32(7):1379-86;87.

2. Ndisang JF, Tabien HE, Wang R. Carbon monoxide and hypertension. J Hypertens. 2004;22(6):105774.

3. Botros FT, Prieto-Carrasquero MC, Martin VL, Navar LG. Heme oxygenase induction attenuates afferent arteriolar autoregulatory responses. Am J Physiol Renal Physiol. 2008;295(4):904-11.

4. Botros FT, Navar LG. Interaction between endogenously produced carbon monoxide and nitric oxide in regulation of renal afferent arterioles. Am J Physiol Heart Circ Physiol. 2006;291(6):2772-8.

5. Ushiyama M, Morita T, Katayama S. Carbon monoxide regulates blood pressure cooperatively with nitric oxide in hypertensive rats. Heart Vessels. 2002;16(5):189-95.

6. Kim YM, Pae HO, Park JE, Lee YC, Woo JM, Kim $\mathrm{NH}$, et al. Heme oxygenase in the regulation of vascular biology: from molecular mechanisms to therapeutic opportunities. Antioxid Redox Signal. 2011;14(1):137-67.

7. Thorup C, Jones CL, Gross SS, Moore LC, Goligorsky MS. Carbon monoxide induces vasodilation and nitric oxide release but suppresses endothelial NOS. Am J Physiol. 1999;277:882-9.

8. Rodriguez F, Zhang F, Dinocca S, Nasjletti A. Nitric oxide synthesis influences the renal vascular response to heme oxygenase inhibition. Am J Physiol Renal Physiol. 2003;284(6):1255-62.
9. Zou AP, Billington H, Su N, Cowley AW, Jr. Expression and actions of heme oxygenase in the renal medulla of rats. Hypertension. 2000;35:342-7.

10. Aizawa T, Ishizaka N, Taguchi J, Nagai R, Mori I, Tang $\mathrm{SS}$, et al. Heme oxygenase- 1 is upregulated in the kidney of angiotensin II-induced hypertensive rats : possible role in renoprotection. Hypertension. 2000;35(3):800-6.

11. Arregui B, Lopez B, Garcia Salom M, Valero F, Navarro C, Fenoy FJ. Acute renal hemodynamic effects of dimanganese decacarbonyl and cobalt protoporphyrin. Kidney Int. 2004;65(2):564-74.

12. O’Donaughy TL, Walker BR. Renal vasodilatory influence of endogenous carbon monoxide in chronically hypoxic rats. Am J Physiol Heart Circ Physiol. 2000;279(6):2908-15.

13. Wiesel P, Patel AP, Carvajal IM, Wang ZY, Pellacani A, Maemura K, et al. Exacerbation of chronic renovascular hypertension and acute renal failure in heme oxygenase-1-deficient mice. Circ Res. 2001;88(10):1088-94.

14. Pradhan A, Umezu M, Fukagawa M. Hemeoxygenase upregulation ameliorates angiotensin IIinduced tubulointerstitial injury and salt-sensitive hypertension. Am J Nephrol. 2006;26(6):552-61.

15. Jadhav A, Torlakovic E, Ndisang JF. Hemin therapy attenuates kidney injury in deoxycorticosterone acetate-salt hypertensive rats. Am J Physiol Renal Physiol. 2009;296(3):521-34. 
16. Artunc F, Amann K, Nasir O, Friedrich B, Sandulache $D$, Jahovic N, et al. Blunted DOCA/high salt induced albuminuria and renal tubulointerstitial damage in gene-targeted mice lacking SGK1. J Mol Med (Berl). 2006;84(9):737-46.

17. Shimamura T. 11-Deoxycorticosterone-induced hypertension, glomerulosclerosis and renal arterial and arteriolar lesions. Jpn J Exp Med 1988;58(5):225-8.

18. Leh $\mathrm{S}$, Hultstrom $M$, Rosenberger $C$, Iversen BM. Afferent arteriolopathy and glomerular collapse but not segmental sclerosis induce tubular atrophy in old spontaneously hypertensive rats. Virchows Arch 2011;459(1):99-108.

19. Ofstad J, Iversen BM. The interlobular artery: its possible role in preventing and mediating renal disorders. Nephrol Dial Transplant 1988;3(2):123-9.

20. Hultstrom M. Development of structural kidney damage in spontaneously hypertensive rats. J Hypertens 2012;30(6):1087-91.

21. Kong JQ, Taylor DA, Fleming WW. Mesenteric vascular responses of young spontaneously hypertensive rats. J Pharmacol Exp Ther. 1991;258(1):13-7.

22. Nilsson H, Folkow B. Vasoconstrictor nerve influence on isolated mesenteric resistance vessels from normotensive and spontaneously hypertensive rats. Acta Physiol Scand. 1982;116(2):205-8.

23. Coelho EB, Ballejo G, Salgado MC. Nitric oxide blunts sympathetic response of pregnant normotensive and hypertensive rat arteries. Hypertension. 1997;30:585-8.
24. Kaide JI, Zhang F, Wei Y, Jiang H, Yu C, Wang WH, et al. Carbon monoxide of vascular origin attenuates the sensitivity of renal arterial vessels to vasoconstrictors. J Clin Invest. 2001;107(9):116371.

25. Kaide J, Zhang F, Wei Y, Wang W, Gopal VR, Falck JR, et al. Vascular CO counterbalances the sensitizing influence of 20-HETE on agonist-induced vasoconstriction. Hypertension. 2004;44(2):210-6.

26. Ndisang JF, Wang R. Alterations in heme oxygenase/carbon monoxide system in pulmonary arteries in hypertension. Exp Biol Med (Maywood). 2003;228(5):557-63.

27. Ndisang JF, Wang R. Age-related alterations in soluble guanylyl cyclase and cGMP pathway in spontaneously hypertensive rats. J Hypertens. 2003;21(6):1117-24.

28. Christodoulides N, Durante W, Kroll MH, Schafer Al. Vascular smooth muscle cell heme oxygenases generate guanylyl cyclase-stimulatory carbon monoxide. Circulation. 1995;91(9):2306-9.

29. Wang R, Wang Z, Wu L. Carbon monoxide-induced vasorelaxation and the underlying mechanisms. $\mathrm{Br}$ J Pharmacol. 1997;121(5):927-34.

30. Rusch NJ, De Lucena RG, Wooldridge TA, England SK, Cowley AW, Jr. A Ca(2+)-dependent K+ current is enhanced in arterial membranes of hypertensive rats. Hypertension. 1992;19(4):301-7.

31. Liu Y, Pleyte K, Knaus HG, Rusch NJ. Increased expression of $\mathrm{Ca} 2+-$ sensitive $\mathrm{K}+$ channels in aorta of hypertensive rats. Hypertension. 1997;30(6):14039. 